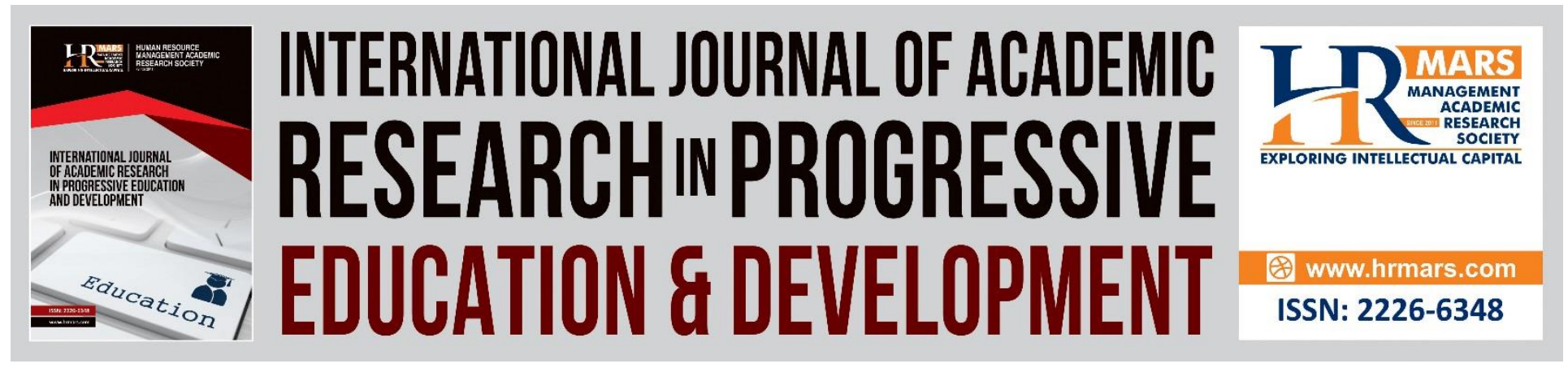

\title{
Motivational Strategies on Volunteering Intention among University Students
}

Al Amirul Eimer Ramdzan Ali, Mohd Azrul Azlen Abd Hamid

To Link this Article: http://dx.doi.org/10.6007/IJARPED/v9-i2/7966

DOI:10.6007/IJARPED/v9-i2/7966

Received: 14 May 2020, Revised: 17 June 2020, Accepted: 30 June 2020

Published Online: 26 July 2020

In-Text Citation: (Ali, \& Abd Hamid, 2020)

To Cite this Article: Ali, A. A. E. R., \& Abd Hamid, M.A. A. (2020). Motivational Strategies on Volunteering Intention among University Students . International Journal of Academic Research in Progressive Education \& Development. 9(2), 702-712.

Copyright: (C) 2020 The Author(s)

Published by Human Resource Management Academic Research Society (www.hrmars.com)

This article is published under the Creative Commons Attribution (CC BY 4.0) license. Anyone may reproduce, distribute, translate and create derivative works of this article (for both commercial and non-commercial purposes), subject to full attribution to the original publication and authors. The full terms of this license may be seen at: http://creativecommons.org/licences/by/4.0/legalcode

Vol. 9(2) 2020, Pg. 702 - 712

http://hrmars.com/index.php/pages/detail/IJARPED

JOURNAL HOMEPAGE

Full Terms \& Conditions of access and use can be found at http://hrmars.com/index.php/pages/detail/publication-ethics 


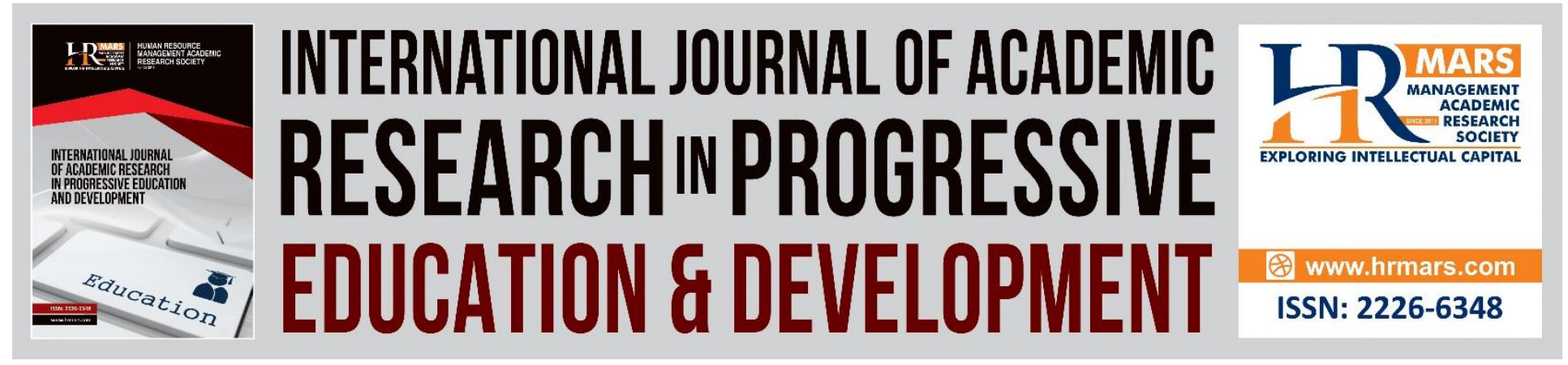

\title{
Motivational Strategies on Volunteering Intention among University Students
}

\author{
Al Amirul Eimer Ramdzan Ali, Mohd Azrul Azlen Abd Hamid \\ Assistant Professor, International Islamic University Malaysia, Malaysia
}

\begin{abstract}
The concept of volunteering is more than just spending one's time in activities that bring benefit to others. Volunteering has a greater impact on society at a larger scale. University's students who actively involved in volunteering activities are of great help to the community as they will have a better chance in learning new opportunities and building new networking people from the industry. This paper aims to investigate the motivational strategies namely intrinsic and extrinsic motivation on volunteering intention among university students. The concept of religiosity is introduced as part of the motivational strategies as it is proven to be one of the students' motivational factor to volunteer.
\end{abstract}

Keywords: Motivational Strategies, Intrinsic Motivation, Extrinsic Motivation, Religiosity, Volunteering Intention

\section{Introduction}

In today's era, volunteerism has become extremely vital in any society, among other reasons, because it includes people who benefit from their service (McCloughan, Batt, Costine \& Scully, 2011). The concept of volunteering has offered the prospect in fostering positive social outcome and community benefits or social capital. In this view, community benefits have been leveraged to explain and creating the awareness on the concept of volunteering to the public. In order to create that awareness, more than one billion people throughout the world involve in numerous volunteering work via public, for profit and non-profit organization (Salamon, Sokolowski \& Haddock, 2011). Furthermore, this concept also is closely related to the helping behavior among people and it ties to long or continuous commitment between both parties (Wilson, 2008 \& Wilson, 2012). When an individual involves in any volunteering work, it is purely on spending his or her time wholeheartedly without hoping anything in return. This is also further supported by Kemp (2002) which stated that volunteerism is a personal investment of people who spend their time helping others without any reward in return. It is also believed that, people who love to involve in volunteering work will develop a more positive behavior and healthier outlook (Sallam, Safizal \& Osman, 2015). This is because, volunteers tend to perceive themselves as optimistic about their future as they feel empowered to assist and improve their community and have that burning motivation to help others who are in need. In today's era, volunteering 
amongst university students is crucial in shaping a community (Hussin \& Arshad, 2012). This is mainly because university students are perceived to be a good catalyst to serve the community as volunteers. In order to measure this, most of studies are linking between theory of planned behavior (TPB) and volunteering intention.

Volunteers devote their time and efforts for a various of reasons. One of the historical ways of recognizing the motivations of volunteers has been based on two theories which are theory of altruism and selflessness (Phillips, 1982; Rehberg, 2005) in which the main motivation of volunteers is to help others. However, there are also other motives that should not be excluded in determining the motivation of the volunteers. According to Rehberg (2005), the motivation of the volunteers often involves more project and few expectations in terms of time, and the intention of volunteering. In this view, numerous studies on volunteerism have found different motivations such as emotional needs, altruism, social contact and altruism (Yeung, 2004). Clary, Snyder, Ridge, Copeland, Stukas, Haugen and Miene (1998) stated that the motivation of the volunteers to volunteer depend on a functionalist approach. According to this approach, different categories of motivational work orientations have been introduced. It also differentiates between motivations for personal development and motivations for affiliation (Barrick, Stewart \& Piotrowski, 2002). Motivations for personal development examine the importance, or preferences for task characteristic in relation to achievement and mastery. On the other hand, affiliation seeks the value of working together as a team. Lastly, functionalist approach has also stated that persuasive messages is vital in encouraging future volunteers to partake in volunteering activities as they feel motivated with the push factors from external parties. In general, motivation can be best defined as the individual's drive to participate in any learning platform. According to Wery and Thomson (2013), there are two (2) main classification of motivational strategies which are intrinsic and extrinsic motivation.

There are few problems and challenges of this study. First and foremost, most of the students and youth do not have the intention to volunteer due to some reasons such as not having enough time, packed with other activities and others. This is also further supported by Sallam et al (2015) where majority of the volunteers are those who have retired from their daily job, while the younger generations are having time and energy as their main obstacle in which hinder their intention to volunteer. Most of the students in universities only focus in getting good grades and will spend their time studying rather than involving in civic activities. In view of this, the government of Malaysia is still focusing on the issues of youth development, especially on how to encourage the youth to be involve in volunteering activities. According to Kulik (2016), there is a vast research being done on motivation and its application to work, however, specific works on the motivation of the volunteers to be involved in volunteering work are scarce and this has to be expended into full research. Secondly, some of the university students are still unsure what type of motivation that will drive them to volunteer. This is further supported by Shye (2009) where some of the volunteers are having "short circuit" problem in which volunteers are leveraging on one or same sets of motivation without exploring for another type of motivation that could assist them in making a firm decision of why they need to volunteer. As students, it is best for them to know what is the main driving force that would enable them to study and at the same time, contributing to the society. Lastly, the concept of religiosity is being introduced as part of the motivational strategies as there are less studies investigated religiosity 
as motivational strategy, attitude and behavior of an individual (Abu-Alhaija, Yusof, Hashim \& Jaharuddin, 2017). This is also further supported by Abdennur (1987) where the concept of religiosity in motivational context was seldom reported. The concept of religiosity mainly focuses on marketing and branding context especially when it comes to purchasing behavior (Bukhari, Hussain, Ahmed, Streimikiene, Soomro \& Channar, 2019).

\section{Literature Review \\ Volunteering Intention}

According to Ajzen (1991), the intention of any individual is the combination of three (3) attributes which are (1) normative beliefs. This belief is best defined as the assumption or behavior that is based on previous experience, (2) behavioral belief which refers to the individual opinion or perspective on any behavior and lastly (3) control beliefs in which the behavior of an individual is shaped by the social pressure. As stated by Ajzen (1991), once the behavioral beliefs are fulfilled, the intention for behavior would vary, in which, the future intentions are highly depending on the expectations about the behavior are met or not. If the expectation about a specific behavior is met, most likely, the individual would have the intention to volunteer or vice versa. Besides of these three (3) attributes, there are few other possible factors that would influence individual's intention to embark on volunteering activities (Sallam et al., 2015). One of the factors is the individual's role identity. As stated by Astrom and Rise (2001), role identity is one of factors that will predict certain behavior or behavioral intentions (Kwon, Trail \& Anderson, 2005).

\section{Intention in Quran and Sunnah}

It is indeed that the intention, motive and objective of individuals reflect their practices. Hence, more than 70 times phrases that are being used in the verses of Holy Qur'an are "in the way of Allah" (fi sabillilah). According to Qaraati (2011), it is important that the practices of individuals must be in line with the way of god. The pillar of worship is intention, and this is will guide the action of individuals. For instance, if an action has no valid intention or the intention is ungodly, hence, the intention will be considered as invalid. If individuals are having mix intentions, most likely, it will affect most of the sacred acts. In Islam, it is the simple actions that are perceived valuable if the intention is pure. This is also in line with The Holy Quran which states:

"Allah does not impose blame upon you for what is unintentional in your oaths, but He imposes blame upon you for what your hearts have earned. And Allah is Forgiving and Forbearing" (Quran 2:225)

\section{Motivation}

The concept of motivation can be best defined as the tendency for human being to do something. As stated by Saedah Siraj and Tuanku Mohani (1996), motivation is also the drive of an individual to achieve goals and missions. Not only that, motivation is perceived as the success plan for an individual and leveraging on this motivation to prevent from any failure (Kamaruddin, Sha'ri, Ghazali \& Hamdan, 2017). One of the most important aspects of motivation is that, students can do something voluntarily and it can be personalized according to their needs and wants in order 
to achieve their goal(s). In this view, if the activities are in line with students' goal and mission, they are willing to be involved in the activities for a long period of time, provided these activities will assist the students to achieve their goal and mission. Through determination and strongwilled motivation, students are also be able to achieve satisfaction and joy in learning new skills and will be made aware of the importance of acquire new knowledge in life. As stated by Azizi and Jaafar (2006), motivation is one of the platforms that allow students to be involved in servicelearning process. Besides, motivation can make the learning process more fun, meaningful, and useful. Each of the individual in this world can be motivated in two (2) ways either intrinsically or extrinsically

\section{Intrinsic Motivation}

Generally, intrinsic motivation occurs when an individual participates in an activity just to know more about something and this is purely based on own initiative. In this view also, intrinsic motivation is a type of motivation where individuals will feel happy internally (Ormond, 2008). Deci, Vellerand, Pelletier \& Ryan (1991), students who are intrinsically motivated will be giving their best effort to complete the assign task or assignments even though with high level of difficulty. These students are also looking forward to contributing to the society and they do not require any reward or incentive in return as they are willing to participate with their own initiative. Once these students have acquired new skills or knowledge, they are likely to retain it as they feel more confident in mitigating difficult situations or tackling some challenging issues. This is because, they able the perception that they are gifted and able to make the best decision on their own (Deci \& Ryan, 1985). Lastly, intrinsically motivated students also will not allow external factors such as people or events to influence any of their decision or action plan.

\section{Extrinsic Motivation}

In contrast to the intrinsic motivation, extrinsic motivation happens when students are rewarded, encouraged or pushed by another person (Gagne \& Deci, 2005). For instance, in university, extrinsically motivated students must depend on the lecturers, classmates in order to get the task or assignment done. Lecturers often reward students with incentive for students to partake in any activity. These incentives can be divided into two (2) which are; tangible reward such as grades and merits whereas intangible reward is more on verbal praise and smile on the lecturers' face (Wery \& Thomson, 2013). Furthermore, extrinsically motivated students undertake any task or assignment for the sake of attaining a reward out of it (Adelman \& Taylor, 1990). This is because, these students always feel that the lecturers' opinion and perception towards them if they do not perform the task well. These students will put their $100 \%$ effort in any task given if the reward is something that is worth fighting for. Lastly, students with extrinsic motivation are known for not able to make their own decision as it is normally controlled by other parties (Kamaruddin et al., 2017).

\section{Religiosity}

Recently, the concept of religiosity has developed as one of the prominent fields of research and there is an increasing interest in investigating the relationship between various dimensions of religion (Shariff, Willard, Andersen \& Norenzayan, 2015). There are several researches that have 
thoroughly tried to reveal the underlying concept of religiosity in organizational life and behavior. The term religion is best defined as the knowledge, practice and perhaps the beliefs of humankind. From the view of researchers and scholars, religiosity is the level of affection between an individual and beliefs and the practices of religion (Voas, 2007). The concept of religion also is more than just believing in god, but it is also about the practices that will govern individual's moral purposes. In other words, religion is the combination of beliefs, instructions on specific practices and the ability of rendering support to those needed while the concept of religiosity is the acceptance and commitment to the combinations required by religion. In this view, religiosity is also the collection of structured practices, norms, cultures and lastly, values. Furthermore, based on the philosophy of Adam Smith, it is stated that religiosity serves as the platform to elevate internal moral of an individual.

\section{Volunteerism from the Perspective of Islam \& Sunnah}

The intention, motive and objective of an individual reflect his or her religion practices. As stated in one of the hadith:

'On the authority of Ameer ul-Mu'mineen (the Commander of the Faithful), Abu Hafs 'Umar ibn al-Khattab radiAllahu anhu, who said: I heard the Messenger of Allah sallAllahu alayhi wa sallam say:

"Actions are but by intentions and every man shall have only that which he intended. Thus he whose migration (Hijrah to Madeenah from Makkah) was for Allah and His Messenger, his migration was for Allah and His Messenger, and he whose migration was to achieve some worldly benefit or to take some woman in marriage, his migration was for that for which he migrated' (Reported in Bukhari and Muslim)

Philanthropy, volunteering, and charity are being perceived as the core of the Islamic commitment towards personal and social obligation. In this view, most of the Muslims consider charity as form of worship to Allah (Ani, 2019). Based on the traditional conceptions of Islam, charity is one of the five pillars of Islam, (alongside with 5 times daily prayers, belief in Allah and the Prophet Muhammad, fasting in the holy month of Ramadhan and pilgrimage to mecca). A charitable act such as volunteering is therefore not just about an act of faith but is about building a community through faith. The act of volunteering focuses on the idea of social justice towards the community and nation. Furthermore, there is a clear expectation that everyone in this world regardless of their faith and religion should be provided with equal opportunities such as education, facilities, and rights. Islam do expect the leaders to assist those who are in need, spending time at the orphanage and Islam also expects all Muslims, whether poor or rich to contribute to such noble cause.

Hence, from the perspective of Islam, there are two (2) forms of volunteerism; sharing the fruits of one's labor which involves money and wealth and secondly, is spending their time to assist others physically (Sulaiman, 2011). The term from Qur'anic referring to these two (2) perspectives of volunteerism are al-mujahadah fi sabil Allah bi al-Amwal (striving to help others in the cause of Allah with goods, money and wealth) and lastly al-mujahadah fi sabil Allah bi alAnfus (striving to help others physically). The explanation of these two (2) forms are as follows: 


\section{Al-mujahadah fi sabil Allah bi al-Amwal (striving to help others in the cause of Allah with goods, money and wealth)}

One of the ways for volunteers to assist others is by leveraging on the money that the volunteer has or by offering physical support. This can be termed as infaq and it can be in various forms such as paying zakah or sadaqah. In this view, zakat and sadaqah can be seen as one of means of spiritual purification (tazkiyat al-Nafs). In order to build true relationship with Allah, Muslims must perform salat, while the concept of zakah and sadaqah resembles the ability to build long relationship among members of society (Sulaiman, 2011).

\section{Al-mujahadah fi sabil Allah bi al-Anfus (striving to help others physically)}

Besides than giving money and wealth to assist others, this form of volunteerism is all about rendering physical labor. For instance, volunteers can render his or her support by vising the sick, helping the homeless and stateless citizens, volunteering at orphanages or any non-government organizations. This also includes providing intellectual support by being a teacher to unfortunate kids who do not have the right to attain education such as stateless kids in Malaysia.

\section{The Relationship between Intrinsic Motivation on Volunteering Intention}

According to Kim, Park, Kim and Kim (2019), in most cases, people who have the intention to be involved in volunteering activities are motivated by intrinsic reward, such as having a pleasure feeling fostered by doing a good job and a sense of doing something that brings benefit to the society. Individuals are looking for a volunteering experience that could assist them in soaring to a greater height. This is also further supported by Cnaan and Goldberg-Glen (1991), where individuals are seeking or perhaps would like to engage in volunteering activities if the experience is intrinsically rewarding and meet their unique needs. This view is also in line with selfdetermination theory where it is about the fulfillment of the psychological needs in any volunteer. Furthermore, intrinsic motivation is vital when students are looking for inherent pleasure and positive feeling when they are involved in any volunteering activity. This is because, students will learn valuable lessons through volunteering activity which is not taught in daily classes. Not only that, intrinsic motivation allows students to partake in volunteering activity because students perceived volunteering as a challenging task coupled with exciting experience (Lee, Reisinger, Kim \& Yoon, 2014). A study by Anderson and Shaw (1999) stated that intrinsic motivation is the determining factor amongst individuals who would like to volunteer in tourism industry.

\section{The Relationship between Extrinsic Motivation on Volunteering Intention}

Extrinsic motivation is the behavior or action that aims to attain some benefit aside from intrinsic satisfaction. In some cases, people may receive benefit from helping those who are in need because the concept of volunteering is extrinsically rewarding as they see this concept as an investment and expect external reward, benefits or payoffs (Meier \& Stutzer, 2004). In this view, extrinsically motivated individuals volunteer because they perceived volunteering as an investment in the human capital as they need to boost future earnings on the labor market (Menchik \& Weisbrod, 1987). People may also volunteer because community service is one of the main criteria for a certain position in a private and government sector. As organization is 
looking for fresh graduate who is not just academically oriented, but the candidate must also be involved in the volunteering activities. This is also further supported by Ashman (2015) where volunteering is a great career move as it improves the candidate's CV. With the tough competition in the market, students are taking this opportunity as a motivation for them to volunteer with the hope to elevate their visibility when it comes to applying for a specific job. Lastly, there is also a positive relationship between extrinsic motivation on volunteering intention because students, working adults are looking into broadening their horizon in the context of network. Meier and Stutzer (2004) stated that volunteering is one of the platforms to make new friends from various industries or sectors.

\section{The Relationship between Religiosity and Volunteering Intention}

It is a fact that religion is one of the utmost important factors of volunteering (Sallam et al., 2017). Although there are various type of religions and religious denomination in this world, all religion has encouraged the spirit of altruism, in which, the inculcation helping behavior, inspire unity and cooperation among members. The general concept of religiosity has elevated the chances for people to volunteer as they are now aware of the benefits of rendering support to other people. There are all together three (3) indicators on how religiosity could affect volunteering intention (Fenyes, 2015). Firstly, is social capital indicator in which the volunteers would be able to build networks while volunteering. Secondly is cultural capital indicator in which the concept of religiosity as the value to build cultural capital and lastly human capital indicator as it creates skills needed for the volunteers to practice and learn prior to volunteering activities. Fenyes (2015) further stated that the relationship between religiosity and volunteering intention involves two (2) theories which are religious belief theory and social network theory. According to the literature, both personal and collective religiosity have a positive impact on volunteering intention. However, according to Monsma (2007), the effect of religiosity on volunteering intention will become stronger if these two (2) factors interact.

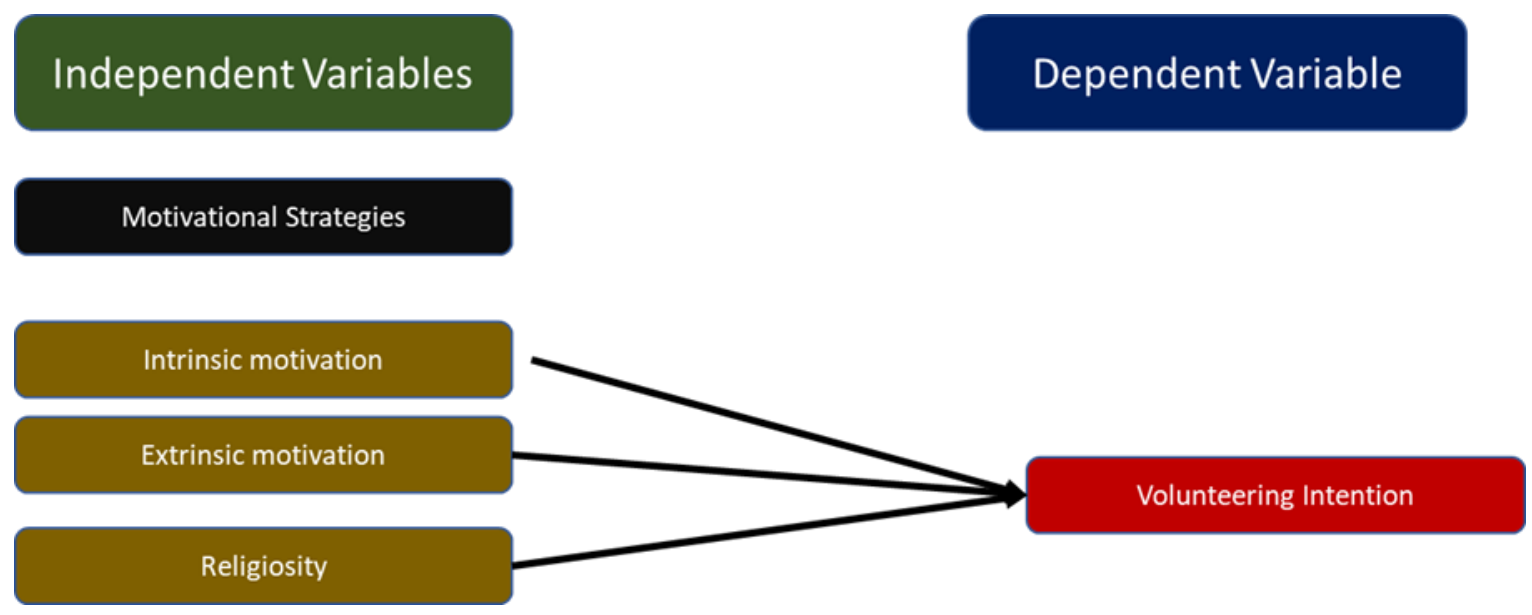

Figure 1. Proposed framework of the study 


\section{Conclusion}

Universities play a critical role in encouraging the students to be involved in community work. Students are more likely to develop few critical skills such as time management and critical thinking, and others while volunteering. Students must take this opportunity to engage in any volunteering activity as the students will have better chance of employment. This is because employers are most likely to choose a candidate with vase experience in volunteering. This conceptual study has elaborated the motivational strategies that give an impact on volunteering intention among university students. It also provides meaningful insights into the concept of religiosity and how it can also be a motivational strategy for students to be involved in volunteering activities. The proposed conceptual framework on this paper hopefully would be useful for scholars and university students. Finally, it is recommended for future researchers to do empirical research on the proposed framework $f$ motivational strategies on volunteering intention.

\section{Acknowledgement}

We would like to thank our research supervisors, reviewers for the constructive feedback. To our family members, colleagues, thank you so much for the support rendered to us.

\section{Corresponding Author}

Al Amirul Eimer Ramdzan Ali, PhD

Assistant Professor

Kulliyyah of Languages and Management

International Islamic University Malaysia (IIUM)

Email: dral@iium.edu.my

\section{References}

Abdennur, A. (1987). The conflict resolution syndrome: Volunteerism, violence, and beyond. Ottawa, Canada: University of Ottawa Press

Abu-Alhaija, A. S. A., Yusof, R. N. R., Hashim, H., \& Jaharuddin, N. S. (2017). The motivational approach of religion: The significance of religious orientation on customer behaviour. International Journal of Economics, Commerce and Management, 5(12), 609-619.

Adelman, H. S., \& Taylor, L. (1983) Enhancing motivation for overcoming learning and behavior problems. Journal of Learning Disabilities, 16, 384-392.

Ajzen, I. (1991). The theory of planned behavior. Organizational Behavior and Human Decision Processes, 50(2), 179-211.

Anderson, M. J., \& Shaw, R. N. (1999). A comparative evaluation of qualitative data analytic techniques in identifying volunteer motivation in tourism. Tourism Manage, 20(1), 99106.

Ani, W. A. (2019). Promoting Islamic Philanthropy: The case of Sultan Qaboos Award for voluntary work in Oman. International Journal of Social Work and Human Services Practice, 7(1), 1-17.

Ashman, L. (2015). How volunteering is a great career move. Retrieved on April 29, 2020 from: https://graduateland.com/article/voluntering-is-a-great-career-move 
Astrom, A. N., \& Rise, J. (2001). Young adults' intension to eat healthy food: Extending theory of planned behavior. Psychology and Health, 16(2), 223-237.

Azizi, \& Jaafar, S. (2006). Siri kaunseling: Membentuk identiti remaja (Counseling series: Establish the identity of the juvenile). Bentong: PTS Profesional Publishing Sdn. Bhd.

Barrick, M. R., Stewart, G. L., \& Piotrowski, M. (2002). Personality and job performance: Test of the mediating effects of motivation among sales representatives. Journal of Applied Psychology, 87(1), 43-51.

Bukhari, F., Hussain, S., Ahmed, R. R., Streimikiene, D., Soomro, R. H., \& Channar, Z. A. (2019). Motives and Role of Religiosity towards Consumer Purchase Behavior in Western Imported Food Products. Sustainability, 12(356), 1-22.

Clary, E. G., Snyder, M., Ridge, R. D., Copeland, J., Stukas, A. A., Haugen, J., \& Miene, P. (1998). Understanding and assessing the motivations of volunteers: A functional approach. Journal of Personality and Social Psychology, 74(6), 1516-1530.

Cnaan, R. A., Goldberg-Glen, R. S. (1991). Measuring motivation to volunteer in human services. Journal of Applied Behavioral Science, 27(3), 269-284.

Deci, E. L., Vallerand, R. J., Pelletier, L. G., \& Ryan, R. M. (1991). Motivation in education: The self-determination perspective. Educational Psychologist, 26, 325-346.

Deci, E., \& Ryan, R. (1985). Intrinsic motivation and self-determination in human behavior. New York: Plenum Press.

Fenyes, H. (2015). Effect of Religiosity on Volunteering and on the Types of Volunteering among Higher Education Students in a Cross-Border Central and Eastern European Region. Social Analysis, 5(2), 181-203.

Gagne, M., \& Deci, E. L. (2005). Self-determination theory and work motivation. Journal of Organizational Behavior, 26(4), 331-362.

Hussin, Z. H., \& Arshad, M. R. M. (2012). Altruism as motivational factors toward volunteerism among youth in Petaling Jaya, Selangor. Psychology, 54(46), 225-229

Kamaruddin, R., Sha'ri, S. N., Ghazali, A. H. A., \& Hamdan, R. (2017). Intrinsic and extrinsic motivation as extralinguistics factors in second language learning among foreign students in five universities of Malaysia. Journal of US-China Public Administration, 14(1), 26-37.

Kemp, S. (2002). The hidden workforce: volunteers' learning in the Olympics. Journal of European Industrial Training, 26(2/3/4), 109-116.

Kim, D., Park, C., Kim, H., \& Kim, J. (2019). Determinants and Outcomes of Volunteer Satisfaction in Mega Sports Events. Sustainability, 11, 1-18.

Kulik, L. (2016). Volunteering during an emergency. A life stage perspective. Non-profit Voluntary Sector Quarterly, 46,419-441.

Kwon, H. H., Trail, G. T., \& Anderson D. F. (2005). Are multiple points of attachment necessary to predict cognitive, affective, conative, or behavioral loyalty? Sport Management Review, 8(3), 255-270.

Lee, C. K., Reisinger, Y., Kim, M. J., \& Yoon, S. M. (2014). The influence of volunteer motivation on satisfaction, attitudes, and support for a mega-event. International Journal of Hospitality Management, 40, 37-48.

McCloughan, P., Batt, W. H., Costine, M., Scully, D. (2011). Participations in Volunteering and Unpaid Work Second European Quality of Life Survey. Eurofound: Dublin, Ireland. 
INTERNATIONAL JOURNAL OF ACADEMIC RESEARCH IN PROGRESSIVE EDUCATION AND

DEVELOPMENT

Vol. 9, No. 2, 2020, E-ISSN: $2226-6348 @ 2020$ HRMARS

Meier, S., \& Stutzer, A. (2004). Is Volunteering Rewarding in Itself? IZA Discussion Paper, 1-32.

Menchik, P. L., \& Weisbrod, B. A. (1987). Volunteer Labor Supply. Journal of Public Economics 32(2). 159-183.

Monsma, S. V. (2007). Religion and philanthropic giving and volunteering: Building blocks for civic responsibility. Interdisciplinary Journal of Research on Religion, 3(1), 1-28.

Ormond, S. (2008). Motivating learners in open and distance learning: Do we need a new theory of learner support? The Journal of Open and Distance Learning, 23(3), 159-170.

Phillips, M. (1982). Motivation and expectation in successful volunteerism. Journal of Voluntary Action Research, 11 (1/2), 118-125.

Qaraati, M. (2011). Intention (niyyah) is the criterion of value in every act including worship.Translator by : Limba M. AhlulBayt World Assembly (ABWA):Iran.

Rehberg, W. (2005). Altruistic individualists: Motivations for international volunteering among young adults in Switzerland. International Journal of Voluntary and Nonprofit Organizations, 16(2), 109-122.

Siraj, S. Z. I., \& Mohani, T. M. (1996). Motivasi Dalam Pendidikan (Motivation in education). Kuala Lumpur: Utusan Publications \& Distributors Sdn. Bhd.

Salamon, L. M., Sokolowski, W. S., \& Haddock, M. A. (2011). Measuring the economic value of volunteer work globally: concepts, estimates, and a roadmap to the future. Annals of Public and Cooperative Economics, 82(3), 217-252.

Sallam, A. A. E. A., Safizal, M., \& Osman, A. (2015). The key drivers of volunteering intention among undergraduate Malaysian students. International Journal of Economics, Commerce and Management, 3(2), 1-13.

Shariff, A. F., Willard, A. K., Andersen, T., \& Norenzayan, A. (2015). Religious priming a metaanalysis with a focus on prosociality. Personality and Social Psychology Review, 20(1), 2748.

Shye, S. (2010). The motivation to volunteer: A systemic quality of life theory. Social Indicators Research, 98(2), 183-200.

Sulaiman, K. U. (2011). Volunteerism from Islamic perspective. International Conference on Humanities, 1-10.

Voas, D. (2007). Does religion belong in population studies? Environment and Planning A 39(5), 1166-1180.

Wery, J., \& Thomson, M. M. (2013). Motivational strategies to enhance effective learning in teaching struggling students. Support for Learning, 28(3), 103-108.

Wery, J., \& Thomson, M. M. (2013). Motivational strategies to enhance effective learning in teaching struggling students. British Journal of Learning Support, 28(3), 103-108.

Wilson, J. (2008). Volunteering. Annual review of sociology, 26, 215-240.

Wilson, J. (2012). Volunteerism Research: A Review Essay. Nonprofit and Voluntary Sector Quarterly, 41(2), 176-212.

Yeung, A. B. (2004). The octagon model of volunteer motivation: Results of a phenomenological analysis. International Journal of Voluntary and Nonprofit Organizations, 15(1), 21-46. 